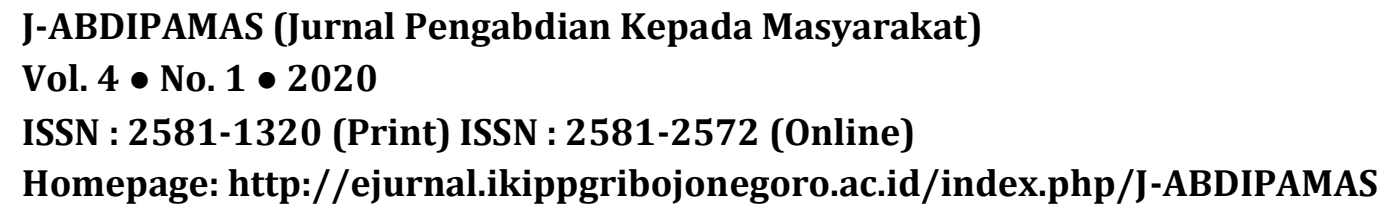

ISSN : 2581-1320 (Print) ISSN : 2581-2572 (Online)

Homepage: http://ejurnal.ikippgribojonegoro.ac.id/index.php/J-ABDIPAMAS

\title{
PELATIHAN PENULISAN BUKU AJAR BAGI GURU DI MA SAFINATUL HUDA SOWAN KIDUL KEDUNG JEPARA
}

\author{
Subaidi $^{1}$, Maswan $^{2}$, Purwo Adi Wibowo ${ }^{3}$ \\ ${ }^{1}$ Universitas Islam Nahdlatul Ulama. Email: subaidi@unisnu.ac.id \\ 2Universitas Islam Nahdlatul Ulama. Email: maswandrs7@gmail.com \\ 3Universitas Islam Nahdlatul Ulama. Email: purwoadiwibowo@gmail.com
}

\begin{abstract}
Textbook writing training is one form of teacher professional development, especially NU teachers as part of local content subjects in the madrasa environment Aliyah Safinatul Huda Sowan Kidul Kedung Jepara. Many MA Safinatul Huda teachers experienced difficulties in writing the textbook. This community service activity is in the form of training in writing textbooks for MA Safinatul Huda Sowan Kidul Kedung Jepara teachers with the aim of; 1) increase teacher motivation in writing good and quality NU textbooks; 2) provide an understanding for teachers about the method of writing good and quality NU textbooks; 3) produce the NU textbook as a learning module. This activity was attended by 30 MA Safinatul Huda Sowan Kidul Kedung Jepara teachers, and was held for 7 times face to face, with details: opening, presenting material 3 times, practicing 2 times and closing. This activity is carried out using the lecture, discussion, question and answer method, and practice. These community service activities have been able to encourage teachers to understand material about textbooks; understand the procedures for the preparation; and made the NU textbook in the Aliyah Safinatul Huda madrasa environment in Kidow Kedung Jepara.
\end{abstract}

Keywords: training, textbooks, teachers

\begin{abstract}
ABSTRAK
Pelatihan penulisan buku ajar merupakan salah satu bentuk dari pengembangan profesi guru, khususnya guru Ke-NU-an sebagai bagian dari mata pelajaran muatan lokal dilingkungan madrasah Aliyah Safinatul Huda Sowan Kidul Kedung Jepara. Guru-guru MA Safinatul Huda banyak yang mengalami kendala dalam penulisan buku ajar tersebut. Kegiatan pengabdian masyarakat ini berupa pelatihan penulisan buku ajar bagi guru MA Safinatul Huda Sowan Kidul Kedung Jepara dengan tujuan; 1) meningkatkan motivasi guru dalam menulis buku ajar Ke-NU-an yang baik dan berkualitas; 2) memberikan pemahaman kepada guru tentang metode penulisan buku ajar Ke-NU-an yang baik dan berkualitas; 3) menghasilkan naskah buku ajar Ke-NU-an sebagai modul pembelajaran. Kegiatan ini diikuti oleh 30 orang guru MA Safinatul Huda Sowan Kidul Kedung Jepara, dan dilakukan selama 7 kali tatap muka, dengan rincian: pembukaan, penyajian materi 3 kali, prktik 2 kali dan penutupan. Kegiatan ini dilaksanakan dengan metode ceramah, diskusi, tanya jawab, dan praktik. Kegiatan pengabdian masyarakat ini telah mampu mendorong guru dalam memahami materi tentang buku ajar; memahami tata cara penyusunan; dan membuat buku ajar Ke-NU-an dilingkungan madrasah Aliyah Safinatul Huda Sowan Kidul Kedung Jepara.
\end{abstract}

Kata Kunci: pelatihan, buku ajar, guru

\section{PENDAHULUAN}

Dunia pendidikan tidak pernah lepas pada kemampuan menulis para pendidiknya. Melalui kegiatan menulis, kemampuan seseorang pendidik akan sangat mudah diketahui. Dalam urut keterampilan bahasa. Untuk mulai menulis, seorang pendidik bisa mulai dari 
sesuatu yang sederhana dan informal, misalnya jurnal/dari kegiatan sehari-hari (N, Listihana, \& Denan, 2018).

Walaupun disana sisni terkait dengan menulis banyak hambatan, sebagaimana pernyataan Kusmaydi (2011) bahwa permasalahan terkait penulisan karya ilmiah yang dialami oleh guru antara lain persepsi bahwa dirinya bukan penulis, sulit memulai tulisan, sulit mengakhiri tulisan, merasa tidak bisa menulis hal-hal hebat, tidak mempunyai ide orisinil, takut salah, menganggap bahwa tulisan yang baik adalah tulisan yang panjang, dan kesulitan membagi waktu untuk menulis (Hayuhantika, 2017).

Guru Ke-NU-an MA di Kabupaten Jepara, terjalin komunikasi melalui sebuah perkumpulan yaitu Musyawarah Guru Mata Pelajaran (MGMP) Ke-NU-an, dibawah naungan Kelompok Kerja Madrasah Aliyah (KKMA) 02 Lembaga Pendidikan Ma'arif NU Kabupaten Jepara. MGMP Ke-NU-an MA KKMA 02 rutin melaksanakan kegiatan perbulan dengan tempat dan lokasi yang bergilir.

Adapun tujuan dari MGMP menurut Direktorat Profesi Pendidik (2008) adalah: 1. Memperluas wawasan dan pengetahuan guru dalam berbagai hal, khususnya penguasaan substansi materi pembelajaran, penyusunan silabus, penyusunan bahan- bahan pembelajaran, strategi pembelajaran, metode pembelajaran, memaksimalkan pemakaian sarana/prasarana belajar, memanfaatkan sumber belajar, dsb.; 2. Memberi kesempatan kepada anggota kelompok kerja atau musyawarah kerja untuk berbagi pengalaman serta saling memberikan bantuan dan umpan balik; 3. Meningkatkan pengetahuan dan keterampilan, serta mengadopsi pendekatan pembaharuan dalam pembelajaran yang lebih profesional bagi peserta kelompok kerja atau musyawarah kerja; 4. Memberdayakan dan membantu anggota kelompok kerja dalam melaksanakan tugastugas pembelajaran di sekolah; 5. Mengubah budaya kerja anggota kelompok kerja atau musyawarah kerja (meningkatkan pengetahuan, kompetensi dan kinerja) dan mengembangkan profesionalisme guru melalui kegiatan-kegiatan pengembangan profesionalisme di tingkat MGMP; 6. Meningkatkan mutu proses pendidikan dan pembelajaran yang tercermin dari peningkatan hasil belajar peserta didik; 7. Meningkatkan kompetensi guru melalui kegiatan-kegiatan di tingkat MGMP (Asmaroini \& Mahardhani, 2019).

Guru-guru madarasah aliyah yang mengampu mata pelajaran Ke-NU-an dilingkungan KKMA 02 LP. Maarif NU Kabupaten Jepara banyak yang masih mendapatkan kendala dalam menyusun buku ajar. Sebagaimana disampaikan Bp. Ubaidillah selaku ketua MGMP Ke-NU-an tingkat MA dilingkungan KKMA 02 kabupaten Jepara dan sekaligus sebagai guru di MA Safinatul Huda Desa Sowan Kidul Kedung Jepara bahwa guru-guru Ke-NU-an khususnya di MA Safinatul Huda perlu memperoleh bimbingan dan pendampingan dalam penulisan buku ajar, karena selama ini belum pernah menyusun buku ajar Ke-NU-an tingkat madrasah aliyah.

Berdasarkan tujuan tersebut, dalam rangka memperluas wawasan guru Ke-NU-an dalam kegiatan proseses pembelajaran di kelas, perlu diadakan kegiatan pelatihan pembuatan buku ajar berupa modul. Modul merupakan bahan ajar cetak yang dirancang untuk dapat dipelajari secara mandiri oleh peserta pembelajaran (Direktorat Tenaga Kependidikan, 2008). 
MA Safinatul Huda merupakan salah satu madrasah yang tergabung di KKMA 02 di bawah naungan LP. Maa'rif NU Kabupaten Jepara yang memiliki 30 orang tenaga pengajar sudah berijasah S1, dan ada yang sedang studi lanjut S2. Beberapa pelatihan yang diikuti oleh para guru telah banyak memperoleh hasil yang cukup signifikan, namun juga masih banyak yang belum begitu banyak memahami terkait dengan penulisan buku ajar. Seperti halnya belum dipahaminya soal bagaimana membuat kutipan daftar pustaka/referensi dengan menggunakan sistem aplikasi komputer, selama ini masih menggunakan sistem manual. Hal ini sangat dibutuhkan ketrampilan guru dalam membuat buku ajar, namun tidak semua guru mampu membuat buku ajar tersebut, dan para guru juga belum mempunyai panduan dalam pembuatan buku ajar. (Nurcahyawati, Sutomo, \& Sunarto, 2018). Solusi yang ditawarkan untuk permasalahan mitra adalah membuat buku ajar KeNU-an bagi guru dilingkungan madrasah Aliyah Safinatul Huda Sowan Kidul Kedung Jepara.

\section{METODE PELAKSANAAN}

Pelaksanaan pelatihan penulisan buku ajar Ke-NU-an bagi guru-guru dilingkungan Madrasah Safinatul Huda Sowan Kidul Kedung Jepara agar berjalan secara baik, maka perlu perlu menggunakan berbagai skenario. Adapun metode yang digunakan dalam pendampingan ini meliputi pelatihan dan praktik dalam membuat buku ajar berupa modul melalui metode ceramah, tanya jawab, dan praktik. Metode ceramah ini dipilih untuk menjelaskan materi tentang penulisan buku ajar yang sangat berguna bagi guru, khusunya guru Ke-NU-an di madrasah alaiyah. Materi yang diberikan terkait sistematika dan teknik penulisan buku ajar, etika dan kaidah penulisan buku ajar. Metode Tanya jawab ini sangat penting bagi para guru selaku peserta pelatihan, baik saat menerima penjelasan tentang materi yang diberikan serta mempraktikkannya. Hal ini memungkinkan guru menggali pengetahuan sebanyak mungkin terkait dengan penulisan buku ajar. Adapun praktik, peserta pelatihan mempraktikkan pembuatan buku ajar dengan bimbingan pelatih sehingga dapat menghasilkan buku ajar yang baik. Dalam pelatihan dan pendampingan guru-guru sebagai peserta diberikan kebebasan untuk bertanya sehubungan dengan penyusunan buku ajar sampai mereka mampu mewujudkan modul Ke-NU-an. Setelah kegiatan berakhir, buku ajar ajar bisa diimplementasikan oleh guru dalam proses pembelajaran di kelas sehingga peserta didik mampu belajar secara mandiri. Adapun langkah-langkah dalam kegiatan tersebut adalah:

a. Memberikan pemahaman tentang buku ajar dan cara membuatnya;

b. Membagi setiap peserta pelatihan untuk praktik mengerjakan buku ajar berdasarkan kelas madrasah aliyah.

c. Mendampingi guru dalam membuat buku ajar sampai terwujudnya karya guru berupa modul Ke-NU-an madrasah aliyah.

\section{HASIL DAN PEMBAHASAN}

Kegiatan penulisan buku ajar telah diikuti sejumlah 30 guru madrasah Aliyah Safinatul Huda Sowan Kidul Kedung Jepara yang mendaftar sebagai peserta pelatihan. Pelaksanaan kegiatan yang telah dilakukan bertujuan memberi wawasan kepada guru 
madrasah Aliyah terkait dengan penyususnan buku ajar. Kegiatan pengabdian masyarakat ini dilaksanakan 25 dan 26 Juli 2019 dengan jumlah peserta 30 orang guru Ke-NU-an dilingkungan madrsah Aliyah Safinatul Huda Sowan Kidul Kedung Jepara. Tujuan dari kegiatan ini untuk meningkatkan motivasi guru dalam menulis buku ajar keNU-an yang baik dan berkualitas, memberikan pemehaman kepada guru tentang metode penulisan buku ajar ke-Nu-an yang baik dan berkualitas, menghasilkan naskah buku ajar ke-NU-an sebagai modul pembelajaran dilingkungan madrasah Aliyah. Kegiatan pengabdian kepada masyarakat ini telah mendorong para guru dalam memahami materi penulisan buku ajar, tata cara penyusunan, dan membuat buku ajar Ke-NU-an dilingkungan madrasah Aliyah Safinatul Huda Sowan Kidul Kedung Jepara.

Kegiatan pelatihan penulisan buku ajar Ke-Nu-an dimulai pukul 08.00 sampai pukul 14.00. Pertemuan hari pertama dilaksanakan di Madrasah Aliyah Safinatul Huda Sowan Kidul Kedung Jepara tanggal 25 dan 26 Juli 2019. Penyampaian materi oleh Dr. Subaidi, M.Pd, Drs. Maswan, MM, dan Purwo Adi Wibowo, M.Si. Adapun materi yang disampaikan tentang konsep buku ajar, konsep modul, dan tata cara pembuatan modul Ke-NU-an tingkat madrasah Aliyah. Dengan demikian guru-guru dilingkungan MA Safinatul Huda Sowan Kidul Kedung Jepara ini telah termotivasi dan memahami terkait dengan metode dalam menulis buku ajar dan modul Ke-NU-an yang baik dan berkualitas. Guru-guru secara tertib dan tekun mengikuti pelaksanaan kegiatan sesuai dengan jadwal yang berlaku. Selama kegiatan ada interaksi dan diskusi yang sangat inten dalam kelas kegiatan. Baik, artinya sesuai dengan standarisasi penulisan buku ajar. Berkualitas, disamping mengikuti standarisasi metode penulisan buku ajar, juga dalam hal ini materimaterinya telah didukung dengan ayat-ayat al-Qur'an hadis Nabi Saw.

Kegiatan hari pertama dapat dilihat berdasarkan gambar berikut:

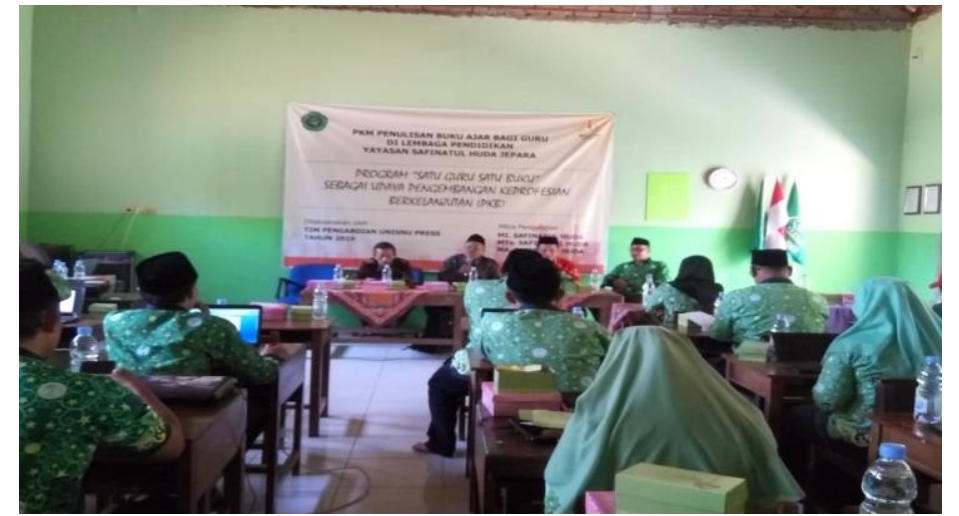

Gambar 1. Penyampaian materi buku ajar

Pada gambar 1 tersebut materi telah disampaiakan. Setelah itu, guru Ke-NU-an madrasah Aliyah diberikan arahan untuk mencoba mencoba mempelajari sistematika buku ajar. Kemudian peserta secara langsung praktik menyusun buku ajar Ke-NU-an madrasah Aliyah Safinatul Huda Sowan Kidul Kedung Jepara. Untuk merealisasikan tujuan kegiatan ini yang terakhir, dari sejumlah 30 peserta, ada seorang guru telah mampu menghasilkan buku ajar Ke-NU-an yang sudah di ISBN kan oleh UNISNU Press dan saat ini sedang proses cetak. 


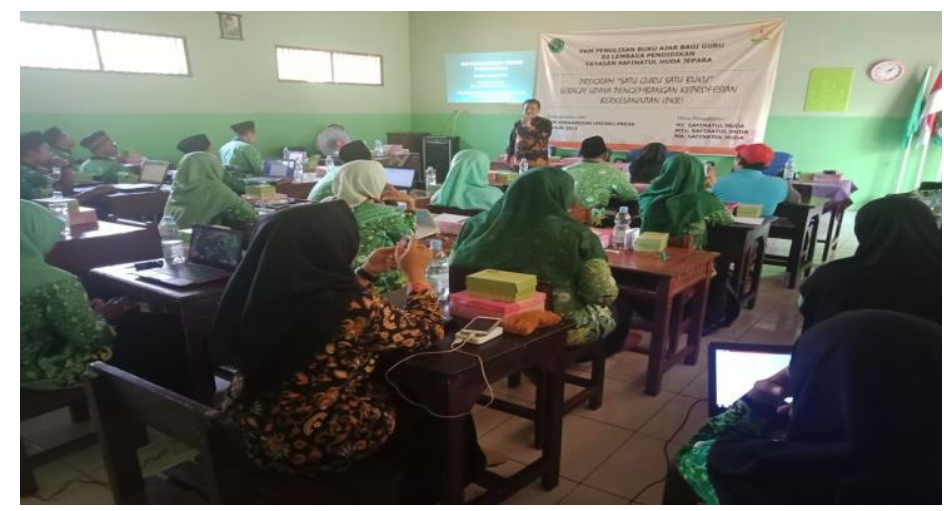

Gambar 2. Pendampingan penyusunan penulisan buku ajar

Kegiatan terakhir dilaksanakan tanggal 26 Juli 2019 di madrasah Aliyah Safinatu Huda Sowan Kidul Kedung Jepara. Pertemuan ini merupakan pendampingan dalam penyusunan buku ajar Ke-NU-an bagi guru madrasah Aliyah. Adapun pertemuan terakhir ini dapat dilihat berdasarkan gambar berikut:
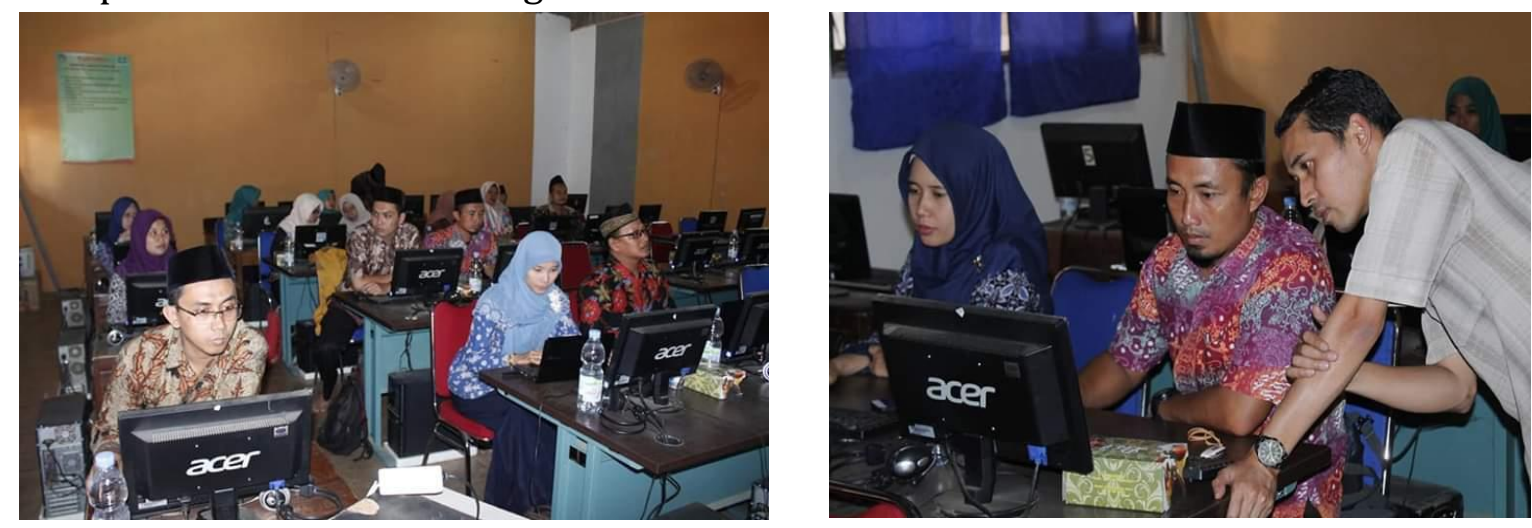

Gambar 3. Pendampingan dalam penyusunan buku ajar

\section{SIMPULAN}

Setelah kegiatan pelatihan penulisan buku ajar bagi guru Ke-NU-an dilingkungan madrasah Aliyah Safinatul Huda Sowan Kidul Kedung Jepara berakhir, sebagai beriku: 1) guru-guru telah termotivasi dan memahami teknik penulisan buku ajar Ke-NU-an secara baik dan berkualitas; 2) guru-guru juga memahami metode penulisan buku ajar Ke-NUan secara baik dan berkualitas, 3) dari jumlah peserta 30 orang guru, ada seorang guru telah mampu menghasilkan buku ajar Ke-NU-an yang sudah di ISBN kan oleh UNISNU Press dan saat ini sedang proses cetak.

\section{DAFTAR RUJUKAN}

Asmaroini, A. P., \& Mahardhani, A. J. (2019). Pelatihan pembuatan bahan ajar bagi guru PPKn MTs di Kabupaten Ponorogo. J-ABDIPAMAS Uurnal Pengabdian Kepada Masyarakat), 3(2) 41-46. Doi http://dx.doi.org/10.30734/j-abdipamas.v3i2.378.

Departemen Pendidikan Nasional. (2008). Proses Penelitian. Direktorat tenaga Kependidikan. Direktoral Jenderal Peningktan Mutu Pendidik dan Tenaga Kependidikan 
Hayuhantika, D. (2017). Pelatihan penulisan karya tulis ilmiah sebagai upaya pengembangan profesionalisme guru SMPN 3 Ngunut, 5, 13-17.

N. A., Listihana, W. D., \& Denan, N. (2018). Mendeley: Untuk meningkatkan kemampuan menulis dosen. J-Abdipamas (Jurnal Pengabdian Kepada Masyarakat), 2(1), 11-20. Doi http://dx.doi.org/10.30734/j-abdipamas.v2i1.182.

Nurcahyawati, V., Sutomo, E., \& Sunarto, M. J. D. (2018). Pembuatan buku digital pada ekowisata mangrove Wonorejo Surabaya. J-ABDIPAMAS (Jurnal Pengabdian Kepada Masyarakat), 2(2), 1-8. Doi http://dx.doi.org/10.30734/j-abdipamas.v2i2.77. 